\title{
Confraternidades negras na América portuguesa do Setecentos ${ }^{1}$
}

\author{
CAIO C. BOSCHI ${ }^{I}$
}

\section{Contexto}

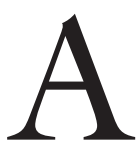

IGREJA que emergiu do Concílio de Trento (1545-1563) parecia ter a nítida noção de que a potencialidade de difusão e ampliação da fé católica

era mais factível e adequada às realidades ultramarinas do que à Europa. Assim, a recuperação do território perdido, na altura, pelo catolicismo ao protestantismo no Velho Continente e o inerente espírito de pregação que emula as religiões fizeram-se sentir com maior vigor em terras extraeuropeias.

A dilatação da fé católica nas conquistas ultramarinas ibéricas esteve diretamente associada ao regime do Padroado que, a despeito de não cuidar de assuntos referentes aos dogmas e à doutrina, orientou e condicionou a política religiosa para o ultramar. Por conseguinte, sem fazer abstração do seu forte viés político-administrativo, os reis portugueses investiam-se na condição de protetores e patronos das ações evangelizadoras nos territórios coloniais.

O labor missionário teve que levar em conta não só as singularidades das diversificadas regiões e localidades em que foi exercido, o estágio cultural e a complexidade do panorama religioso com que deparava, bem como a realidade geopolítica, posto que variados eram os momentos e as formas de contato e de empenho na propagação da catolicidade.

Nessa dimensão, para a análise do tema-objeto anunciado no título deste texto, há que fazer rápida menção aos seus antecedentes extraeuropeus, em particular ao chamado cristianismo africano, experiência de cristianização da África Central que se constituiu em variante do catolicismo ocidental, por proceder à reinterpretação dos símbolos e práticas cristãs, impondo-se, assim, como importante fator na compreensão da história política e cultural dos africanos e seus descendentes afro-americanos (Reginaldo, 2011, p.71-2).

A destacar que cristianismo africano é enunciado conceitual fluido, permitindo equívocos, como levar a supor a sobreposição do catolicismo às crenças religiosas africanas. Assim, o “rótulo de 'cristianismo africano' torna-se uma forma bastante conveniente para descrever a religião congolesa em termos gerais". Todavia, "o perigo dessa formulação é o fato de diluir o núcleo cosmológico congolês". Afinal, os "congoleses não eram apenas cristãos. [...] o Cristianis- 
mo e a religião congolesa indígena funcionavam paralelamente, sendo que a cosmologia centro-africana continuava a ser o paradigma religioso dominante para a maioria dos congoleses, em especial durante o processo de conversão ao Cristianismo" (Swett, 2007, p.138). ${ }^{2}$

Por outro lado, na América portuguesa, os escravos africanos e seus descendentes, ao aceitarem elementos do catolicismo não o fizeram à custa de suas cosmologias de origem. As práticas africanas não foram obliteradas. Baseados em semelhanças simbólicas, eles procederam sim à naturalização do catolicismo integrando traços coincidentes com suas mundivivências, africanizando símbolos e crenças católicas, crioulizando formas religiosas da Igreja Católica, no que se pode entender como catolicismo afro-brasileiro, que teve nas irmandades laicas uma das suas expressões mais vigorosas (Sweet, 2007, p.238 e 252).

A assinalar a ambivalência na utilização do conceito, seu estatuto de reciprocidade, isto é, a demonstração de que houve identicamente a aproximação dos brancos às formas africanas de religião, a adoção e o impacto de elementos das crenças e práticas religiosas africanas no catolicismo brasileiro. Como observa James Sweet (2007, p.265),

[...] africanos e europeus trocaram ideias religiosas no Brasil, naturalizando elementos dos sistemas uns dos outros, de forma a responder a diferentes problemas. [...] Como ponto de confluência de vários mundos, africanos e europeus, a essência religiosa e cultural do Brasil Colonial não era nem portuguesa nem africana. Ao mesmo tempo, também não se tratava de uma mistura crioulizada e indiferenciada. Pelo contrário, o Brasil foi a soma de partes distintas e, por vezes, contraditórias.

Além disso, na América portuguesa, em matéria de práticas religiosas, ambivalência não significava incompatibilidade. "Era possível acreditar em Nossa Senhora do Rosário e acreditar em divindades do panteão africano, sabendo que elas mantinham suas respectivas identidades" (Oliveira, 2008, p.34).

Tendo em conta essas premissas, retorne-se à essência de nosso propósito, afirmando, desde logo, que, qualquer análise respeitante às manifestações religiosas na colônia tem no estudo da atuação das irmandades um de seus pontos incontornáveis. É nelas e por intermédio delas que tal religiosidade predominantemente se expressou. Promotoras e sedes de devoção religiosa, essas instituições, além de veículos de sustentação material do culto católico na colônia, desoneraram o Grão-Mestrado da Ordem de Cristo do dever de aplicar, consoante os preceitos que lhe deram origem, os dízimos eclesiásticos por ele recolhido.

Inspiradas nas suas homônimas metropolitanas, as confrarias americanas apresentavam, no entanto, significativos traços de peculiaridade, quando nada porque os "africanos e seus descendentes, por mais que isso refutasse as expectativas do Estado e da Igreja, não eram tabulas rasas. Souberam eles, de forma criativa, apropriarem-se do culto católico e reconstruí-lo com base na experiência do cativeiro e nas recordações memoriais das diversas culturas africanas que aportaram na América em função do tráfico atlântico" (Oliveira, 2008, p.324). 
Em síntese, não seria equivocado afirmar-se que, por meio e no interior das irmandades de negros e seus descendentes, emergia um processo de africanização da religião católica. Um catolicismo negro ou africano, conforme expressão cunhada por historiografia recente, tendo em vista que, desde o século XVI, o catolicismo se disseminara pela África Central, do que resultou, dentre outras realizações, na constituição de irmandades leigas.

\section{O objeto de estudo}

No melhor estilo tridentino de doutrinação e de enquadramento dos fiéis, as irmandades (aqui tomadas como sinônimo de confrarias, apesar de diferenças conceituais) significaram a entidade na qual os leigos assumiram lugar central na divulgação do catolicismo nas conquistas portuguesas, visto que foram eles os próprios agentes não apenas de sociabilidade, mas também os promotores das cerimônias e dos atos devocionais.

O advento das confrarias nesses domínios espaciais foi obra de diversas ordens religiosas, e, secundariamente, de padres e de prelados. De todo modo, porque não se restringiam a ser entidades de natureza exclusivamente religiosa, as irmandades coloniais foram se independentizando em relação às paróquias e aos religiosos ou às suas respectivas ordens primeiras, construindo as suas próprias capelas e igrejas, absorvendo os clérigos nos seus quadros sociais na qualidade de meros filiados e, em certos casos, de celebrantes dos ofícios religiosos.

Data de 1552 o surgimento das primeiras irmandades conhecidas que se criaram na América portuguesa. Estavam sob a invocação de Nossa Senhora do Rosário e foram erigidas na capitania de Pernambuco. Sendo agremiações compostas por "gente de cor", a essas confrarias se somaram as de São Benedito, São Elesbão e Santa Efigênia, igualmente evocados pelas populações negras.

Com efeito, o culto dos santos constituiu-se numa porta de entrada dos negros na fé católica, sobretudo pelo caráter humano com que os africanos os distinguiram, tornando-os "mais receptivos às necessidades específicas da sua comunidade imediata", transformando-os em paladinos de suas causas e "em espíritos de antepassados, à maneira africana" (Sweet, 2007, p.240-2). ${ }^{3}$

No Brasil colonial, a devoção aos "santos pretos" se apresentou como explícita estratégia de ação de cristandade para o processo de catequese dos negros, sobretudo no século XVIII, pelo que se lê em "projeto elaborado por ordens religiosas mendicantes de cunho marcadamente urbano, nomeadamente os franciscanos e os carmelitas". Trata-se da produção de textos facilitadores da recepção do culto aos santos pelas coletividades negras. Citem-se dois exemplos: a obra do frade carmelita José Pereira de Santana, Os dois atlantes de Etiópia: Santo Elesbão, imperador XLVII da Abissinia. Advogado dos perigos do mar \& Santa Efigênia, princesa da Núbia, advogada dos incêndios dos edifícios. Ambos carmelitas, escrita e publicada entre 1735 e 1738, na qual Elesbão e Efigênia são apresentados como "santos pretos carmelitas destinados à devoção dos negros, inicialmente cultuados em igrejas da Ordem do Carmo e, aos poucos, nominan- 
do e adornando irmandades leigas daqueles segmentos sociais. A outra, a do frei franciscano Apolinário da Conceição, de 1744, intitulada Flor peregrina por preta, Ou nova maravilha da graça, descoberta na prodigiosa vida do beato Benedito de S. Filadelfio, religioso leigo da Província Reformada da Sicilia, da mais estreita Observância da Religião Seráfica (Oliveira, 2008). ${ }^{4}$

$\mathrm{Na}$ América portuguesa, os oragos mais recorrentes foram os do Santíssimo Sacramento, os das Almas e o de Nossa Senhora do Rosário, evocações particularmente estimuladas pelas orientações emanadas de Trento, embora preexistentes e disseminadas antes do conclave.

Fixemo-nos na Senhora do Rosário. Tendo expressiva ressonância no restante da Europa, o culto do Rosário chegou a Portugal possivelmente no século $\mathrm{XV}$, por obra de frades dominicanos, comunidade religiosa com a qual passou a ser identificado. Um intenso tráfico de escravos africanos para aquele país, nos séculos XVI a XVIII, delineia melhor o quadro. Assim é que, em 1551, na igreja do Convento de São Domingos, em Lisboa, havia duas irmandades sob a égide da Senhora do Rosário: uma, instituída por pessoas brancas; outra, formada por pretos e forros. Ainda no século XVI, duas outras confrarias exclusivamente integradas por negros se constituíram na capital portuguesa, aumentando seu número nas centúrias seguintes, não se limitando geograficamente a Lisboa. Encontramo-las também em Évora, no Alentejo, no Algarve e na cidade do Porto (Lahon, 1999; 2001; Reginaldo, 2011, p.51, 60-72). Na colônia, no entanto, dada a ausência de dominicanos no processo de evangelização, esse culto foi disseminado pelos inacianos.

A escolha do orago não estava necessariamente associada ao trabalho evangelizador levado a efeito por uma ordem religiosa no local ou nas proximidades de instalação das confrarias. Essas congregações, por sinal, poderiam nem sequer participar do processo de propagação da fé em determinados contextos nos quais o florescimento de irmandades sucedeu com irrefutável vigor. Aponte-se o caso da capitania de Minas Gerais onde, no século XVIII, as ordens religiosas foram proibidas de se estabelecer (Boschi, 1986; 1999). Por tudo isso, afirme-se que a escolha de oragos se vinculava essencialmente às origens sociais, à proeminência geográfica e à categoria socioprofissional dos confrades.

\section{Presença das irmandades}

Para quem quer que fosse, na realidade sócio-histórica aqui considerada, tornava-se incontornável a adesão a uma ou mais dessas associações. Por questão de vida e de morte. Literalmente. De vida, pois no interior delas o confrade encontrava segurança e consolo espirituais, como também ali desenvolvia suas relações e convívio sociais, ainda a elas se socorrendo quando da necessidade de submeter-se a eventuais cuidados médicos, ou mesmo para a obtenção de empréstimos pecuniários. De morte, porquanto não pertencer aos quadros sociais de uma dessas agremiações, significava não ter local para sepultamento de seu corpo, ficar na incerteza da celebração de missas votivas e de sufrágios para a salvação da alma. ${ }^{5}$ 
Em outras palavras, as irmandades cuidavam de oferecer uma maior sensação de segurança e proteção, o exercício da mutualidade e a garantia prévia de sepultamento condigno e de missas pelas almas de seus adeptos, procurando confortá-los diante das incertezas e agruras da realidade colonial. Saliente-se, a propósito, que a preocupação com a salvação eterna era das motivações decisivas para o ingresso em uma ou mais irmandades. Também aqui um traço significativo: nos testamentos dos irmãos, a definição do sepultamento, a destinação de esmolas caritativas e, sobretudo, a determinação de copiosas missas votivas eram vontades enfatizadas e, em grande parte dos registros, enunciadas com maior relevância do que as especificações dos bens destinados aos descendentes e a outros entes queridos do testador. ${ }^{6}$ Acrescente-se que, em certas associações, na falta do irmão, elas prestavam auxílio à sua viúva e aos filhos órfãos. Tudo isso sem considerar que a filiação a esses grêmios proporcionava, a todos e a cada um, maior visibilidade no corpo social, ou seja, a superação do anonimato.

$\mathrm{Na}$ óptica da coroa, e para sua relativa tranquilidade, assim constituídas, as irmandades funcionavam como eficiente fator de equilíbrio social. Perante o Estado, laica era a elite, laicos eram igualmente as camadas populares e os escravos. Ou seja, o sistema colonial hierarquizava as confrarias, mas não fazia distinção formal entre religiosidade popular e religiosidade da elite. Além disso, no Brasil colonial, as confrarias, de um lado, foram mecanismos de controle social, de outro - se não o único -, o mais consistente meio de inserção de negros e mestiços no processo de interação social.

Para os negros, na ordem escravista colonial em que se viram lançados, as irmandades facultavam-lhes a identidade coletiva, possibilitando-lhes sair das franjas e da exclusão sociais, conferindo-lhes um nível, mínimo que fosse, de distinção social. Enfatize-se, no entanto, que a condição escrava se constitui em fator essencial seja na formação, seja, principalmente, nas relações internamente desenvolvidas pelos seus integrantes.

\section{Circularidade cultural}

Para uma sociedade e um Estado com tão fortes conotações ideológicas como as existentes no vasto império português setecentista, sobretudo naquelas áreas onde se estabeleceram relações sociais apoiadas no escravismo, tornava-se primordial a utilização de mecanismos que transmitissem às populações uma falsa sensação de igualdade social. As irmandades era um desses instrumentos, talvez o mais eficaz.

No plano religioso, elas espelhavam a ideia de que, se a todos era permitida a formação de um ou mais sodalícios, havia igualdade de oportunidades. Raciocínio falacioso, pois igualar os homens perante Deus não anula a desigualdade existente entre eles enquanto corpo social.

$\mathrm{Na}$ óptica do Estado absolutista, a ideologização das confrarias permitia-lhe perceber e, por decorrência, canalizar a seu favor ou neutralizar com maior facilidade as manifestações sociais que lhe eram adversas. Por meio das irmanda- 
des, o Estado tentava obter a conciliação de antagonismos sociais. Nessa medida, era fundamental para ele que as confrarias não se transformassem em veículos contestatórios ou desestabilizadores do sistema colonial.

Nesse quadrante, a adesão dos indivíduos às irmandades, conquanto fosse necessidade basilar para todos, no sentido de se obter proteção e segurança, para além de canal de interlocução social, não provocava nos associados indispensavelmente uma consciência de grupo. O prestígio social das irmandades não teve correspondência no plano da práxis política. Em outras palavras, o que se almejava em relação, verbi gratia, às populações escravas nas colônias era o estabelecimento de uma perfeita heteronomia social.

Instrumento de dominação, para os negros escravos, porém, as irmandades se traduziam em relevante campo de liberdade. Por conseguinte, assimilar em maior ou menor dose a cultura europeia foi decisão que variou conforme a circunstância e a vontade dos confrades. De qualquer forma, é indubitável que, por intermédio das suas irmandades, aqueles segmentos puderam cultivar e preservar elementos e práticas culturais que, muito possivelmente, teriam desaparecido se outro fosse o contexto.

Nessa perspectiva, as irmandades de negros, ao reinterpretarem a religião dos dominadores brancos, nuançavam o permanente conflito social e as violências que permearam todo o período colonial. A aparência de conformismo e passividade acabava por esconder o antagonismo latente (Mello e Souza, 2002, p.233).

\section{Sincretismo}

$\mathrm{Na}$ interpretação de uma especialista, a integração dos negros ao Novo Mundo exigiu

[...] o desenvolvimento de relações com os companheiros na mesma condição, africanos ou crioulos, e com os senhores que exploravam seu trabalho e aos quais deviam submissão. Dessa forma, na América colonial, pessoas submetidas a um mesmo sistema de dominação tiveram que lidar com as tensões inerentes às diferenças entre as várias etnias, e com aquelas advindas do sistema escravista. Assim, imersas em múltiplos conflitos, elaboraram formas de organização social que incorporaram contribuições africanas e influências dos senhores de origem europeia. Ao lado da diversidade dessas contribuições, as determinações do sistema escravista foram fundamentais na elaboração das novas formações sociais. (Mello e Souza, 2002, p.149)

Ao serem aprisionados, vendidos e transportados para outros continentes, os negros, porém, não prescindiam das suas divindades e das suas visões do mundo. Impossível imaginá-los com uma postura receptiva e passiva dos padrões culturais e religiosos daqueles que os haviam subjugado. $\mathrm{O}$ incremento do tráfico negreiro no século XVIII teve, assim, como corolário, a intensificação do entrecruzamento de sistemas simbólicos e de intercâmbio religioso. As irmandades foram loci privilegiados para se captar esses fenômenos sincréticos. 
Numa tendência secular, como no caso, e tendo em vista a variedade dos contextos regionais abrangidos, não se pode ajuizar genericamente sobre o grau, a intensidade e as ressonâncias das manifestações sincréticas no Brasil setecentista.

De todo modo, insista-se, ao fundarem suas irmandades, os negros não estavam a incorporar inequivocamente padrões culturais dos brancos. Na realidade, continuavam a agarrar-se aos seus passados étnicos particulares, que eram, então, retomados. De acordo com Sweet (2007, p.21-11 e 141-3),

[...] no Brasil dos séculos XVII e XVIII, as religiões não eram sincréticas ou crioulas, mas sim sistemas de pensamento independentes, praticamente em paralelo com o catolicismo. Quando ocorriam de fato misturas religiosas significativas, como se verificou a partir do século XVIII, este sincretismo era essencialmente evidente entre Ganguelas e Minas, ou entre Ndembos e Ardas - e não entre africanos e católicos portugueses.

Com efeito, no interior das suas confrarias e nos eventos públicos que promoviam ou de que participavam, os negros africanos inseriam suas tradições e costumes de origem. Por conseguinte, nem sempre se efetivou sua integração no catolicismo dominante, como hipotética também era uma efetiva redefinição da religião anteriormente praticada pelos negros, no interior das confrarias por esses instituídas.

O que importa é que, no geral, assimilados culturalmente em maior ou menor intensidade, preservando (ou não) a autenticidade dos seus costumes e tradições de origem, os negros africanos introduziram elementos e componentes na cultura religiosa da América portuguesa, que, só por isso, já se mostraria distinta e original.

Em rigor, esses negros chegavam ao Brasil tendo adquirido ou assimilado pouco mais do que rudimentos do catolicismo. Na África, ao serem vendidos como escravos ou embarcados em tumbeiros com destino à América ou à Europa, de conformidade com disposições eclesiásticas e civis, eles deveriam ser instruídos nas verdades da religião católica e batizados antes do embarque.

É fácil supor o grau sumário dessa catequese e da ineficácia desses batismos, ${ }^{7}$ mormente levando-se em conta a pressão dos traficantes que acintosamente reclamavam dos prejuízos causados pela "demora" na instrução religiosa ministrada pelos sacerdotes católicos. Importa assinalar que esses expedientes, em última análise, funcionavam como instrumentos de sacralização do tráfico negreiro.

Recorra-se a testemunho de época. No início do século XVIII, autoridades eclesiásticas da América portuguesa denunciavam ao bispo de Angola, D. Luís Simões Brandão (1701-1719), "que os negros que ali chegavam sabiam apenas que tinham sido batizados, mas que não sabiam quem era Deus nem conheciam a lei de Cristo. Muitos destes escravos iam para o campo onde morriam sem fé e sem sacramento e continuavam a praticar os ritos pagãos" (apud Gabriel, 1978, p.163). 


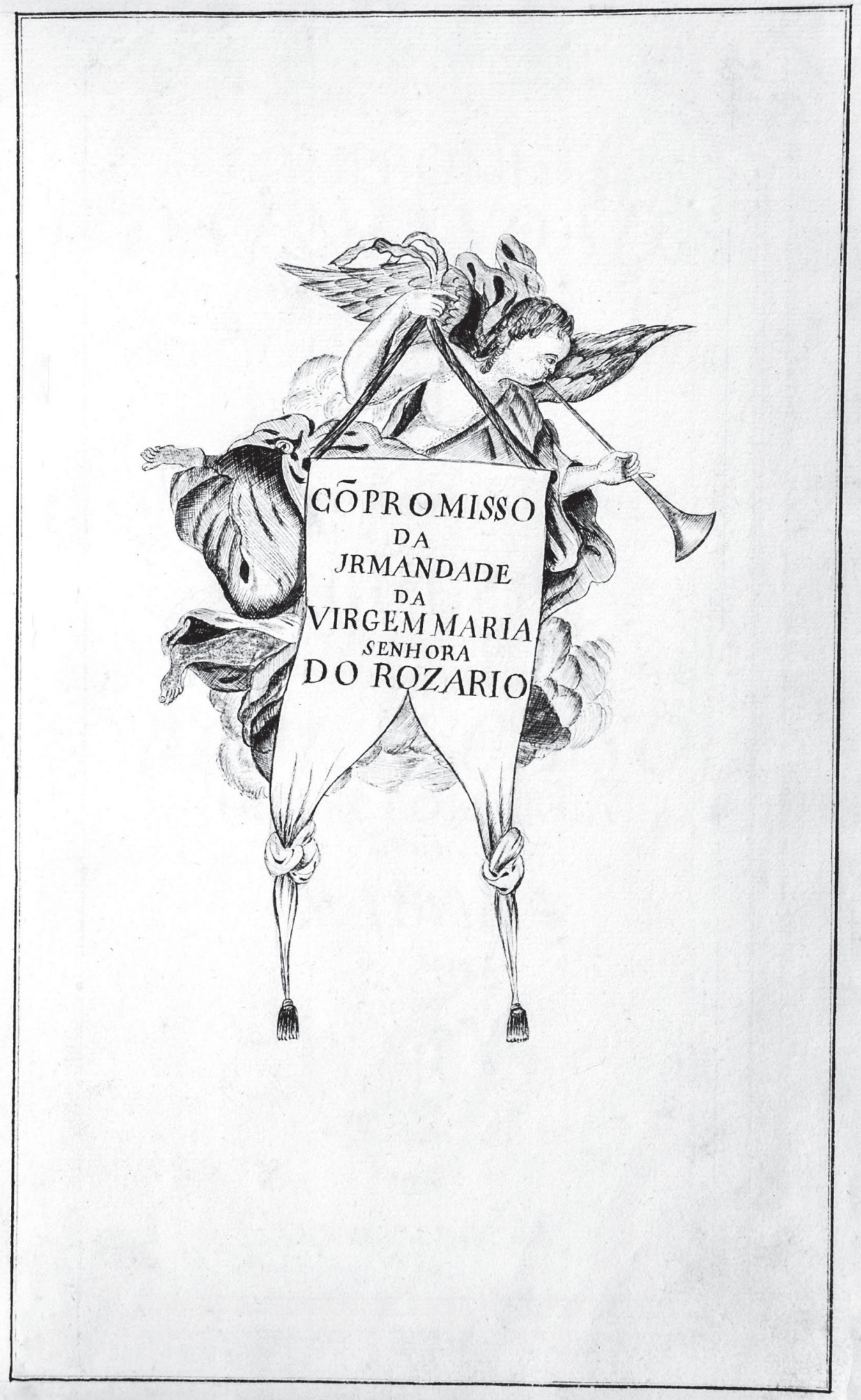




\section{COMPROMISSO \\ DAIRMANDADE \\ DA}

VIRGEM SENHORA DOROZARIO

DOS PRETOS

$D O$

ARRAYAL DO MORRO VERMELHO

$D A$

FREGUEZIA

DA SENHORA

DO

BOM SUCESSO

DO CAETE COMAR CA
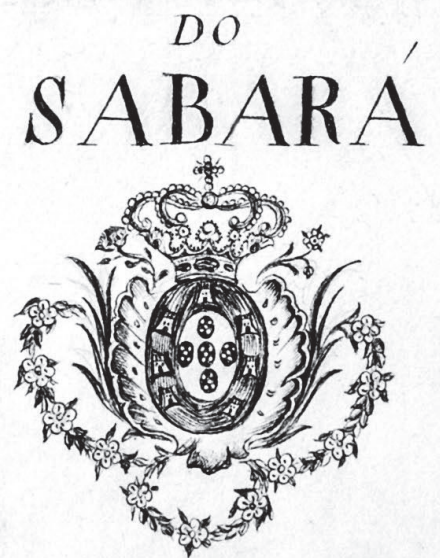

ANNO M.DGG. XG. 
Ora, diante desse quadro, não surpreende que, ao depararem com outra realidade, na qual foram compulsoriamente inseridos, a reação desses africanos tenha sido a de incorporação dos padrões comportamentais e, sobretudo, da absorção da religião dos brancos, de que, quando tinham algum conhecimento ou vivência, essas não ultrapassavam o estágio mais elementar. A bem dizer,

[...] a aceitação do Cristianismo por parte dos africanos foi lenta e desigual, e mesmo quando parecem registrar-se manifestações de devoção à fé cristã, continuam a poder ser encontrados elementos do passado religioso africano em coexistência com as práticas cristãs. [...] Ao mesmo tempo que os africanos adotavam gradualmente alguns elementos da fé católica, contribuíram também para transformar a Igreja brasileira, deixando uma marca indelével no panorama religioso do Brasil Colonial. (Sweet, 2007, p.225)

O sincretismo afrocatólico dos escravos foi o tonus hegemônico, como não poderia deixar de ser, tratando-se de um período no qual o tráfico negreiro africano em direção principalmente à América portuguesa era a mola-mestra da economia e da sociedade no Atlântico Sul português.

Irmandades, espaço de inserção, mas também de resistência. Nas atividades confraternais das agremiações de "homens de cor" eram inequívocas as manifestações cuja marca é a preservação de valores africanos e a reconstrução de identidades, como se expressava nas de coroação de reis do Congo.

\section{Exclusivismos étnico-nacionais}

O estudo da composição dos quadros sociais das irmandades formadas por escravos africanos chegados ao Brasil nos séculos XVI e XVII é dificultado pela inexistência de documentação substanciosa, em particular daquela produzida pelas próprias associações. Tudo indica, todavia, que, na diáspora e em seus momentos iniciais, elas não foram reprodução, na América, de etnias ou de nações africanas. Não eram "sociedades étnicas disfarçadas”, ou seja, entidades nas quais a adesão ficava restrita aos membros de certas etnias africanas, e cujas atividades almejavam a perpetuação das suas tradições religiosas e sociais (Sweet, 2007, p.243).

Essas assertivas não invalidam as evidências de que, em grande parte das irmandades negras da América portuguesa, tenha havido a hegemonia de determinados "grupos de procedência", ou seja, daqueles que, conforme senso comum, seriam originados de localidades específicas. Por certo, esses grupos são heterogêneos, seja porque têm composição étnica distinta, seja porque suas origens também não são as mesmas. Assim, não obstante a primazia, a prevalência e o controle exercido pelos negros “angolas" nas irmandades de Nossa Senhora do Rosário na Bahia, em Pernambuco, no Rio de Janeiro e em São Paulo (Sweet, 2007, p.243; Soares, 2000, p.188; 2002, p.60; Reginaldo, 2011, p.312-13; Silva, 2003, p.77-96; Lima, 1999, p.11-38) há que ressaltar suas especificidades. Reginaldo (2011, p.302) registra que,

[...] na Bahia, assim como em outras partes do Brasil, o termo angola era usado para identificar diferentes populações embarcadas para a América prin- 
cipalmente através de Luanda, porto e capital do mais importante enclave português na costa africana. Podia tratar-se de povos originários das imediações da costa, ou ainda, de populações escravizadas em regiões distantes do domínio português, mas integradas ao circuito do tráfico interno e atlântico.

Reitere-se: primazia, prevalência, não exclusividade, posto que as origens étnicas não são determinantes na formação e no cotidiano das irmandades de negros do Brasil escravista (cf. Lima, 1999). É nessa perspectiva que Lucilene Reginaldo (2011, p.153), baseando-se nas análises de Mintz e Prince (1992) e de Lovejoy (2002), chama a atenção para as reservas que se devem ter em relação às interpretações calcadas nos referenciais de procedência africana na organização das confrarias baianas, entendendo a constituição dessas associações como procedimentos e espaços de "sobrevivências" de elementos culturais e religiosos africanos no Novo Mundo. Ou seja, destaca que, não obstante o reconhecimento da importância da distinção étnico-nacional, "a relação entre as experiências identitárias africanas e aquelas vividas no outro lado do Atlântico mantêm relações mais complexas que a de simples transposição" (ibidem). Afinal, à identidade grupal, vinculada às origens africanas, se somam as experiências do cotidiano no mundo e da dinâmica da escravidão americana, nele incluídas as relações “entre os africanos de várias procedências e entre eles e os outros personagens do cenário social para o qual foram transpostos" (ibidem, p.155).

Assim, estabeleceram-se pactos interétnicos, permitindo dizer-se que "o reconhecimento das alianças entre africanos na formação das confrarias na Bahia setecentista oferece um excelente panorama dos arranjos da etnicidade" (ibidem, p.155-6).

Tal realidade não deve ofuscar a existência e o exercício de regras restritivas ou de exclusão (baseadas apenas na cor ou na origem étnica) por parte dessas confrarias. Considere-se, exemplificadamente, a prática da permissão para a adesão indistinta de irmãos, mas com a ressalva da preservação da esfera de poder, isto é, que os cargos diretivos - na totalidade ou específicos - ficassem reservados a membros oriundos de determinado segmento sociotribal ou a grupo étnico. ${ }^{8}$

O procedimento denota que "a exclusão, quando interveniente, apontava menos para algum tipo de seleção de caracteres culturais e mais para processos de relacionamento político entre grupos específicos [...] um ato político, portanto, já que ditado mais por relacionamentos que pela busca de homogeneidade do ponto de vista cultural” (Lima, 1999, p.22). Em outros termos, “[...] o clamor de irmandades por uma certa identidade - seja africana, seja local respondia mais à necessidade política de estabelecer um poder de barganha nas interações entre escravos e entre cativos e livres que ao aferramento a elementos primordiais africanos efetivamente herdados" (ibidem, p.32).

\section{Festas}

Ao transferir às populações coloniais os ônus financeiros com o culto religioso, a coroa portuguesa alimentou naquela gente o espírito de competitivi- 
dade, que, no âmbito das irmandades, se expressou, de variadas formas. Quiçá a mais evidente para se perceber as disputas entre os sodalícios sejam as procissões. Ou melhor, os litígios em torno da organização das procissões e de outras cerimônias públicas. Quem tinha precedência no cortejo processional? Quais critérios orientavam essa definição? Diante da existência de mais de uma irmandade de oragos idênticos, qual delas tinha precedência nos séquitos? E assim por diante. As sociabilidades não excluíam os conflitos. Litigava-se por tudo e contra todos, em pleitos que, por vezes, alcançando a via judicial, se arrastavam por vários anos. Com as desavenças, o que se buscava era obter maior visibilidade, isto é, adquirir maior prestígio social, preservar privilégios, impor-se ao respeito da comunidade. Jogo de poder, em última análise.

O quadro de discórdias não invalida a sua antítese. Assim, registre-se a existência de solidariedade e de ajuda recíproca entre as confrarias. Era comum, por exemplo, que as despesas com as festas dos seus patronos fossem custeadas equitativa ou proporcionalmente pelas associações abrigadas no interior de uma mesma igreja. Cooperação mútua e reciprocidade de interesses era também o que se observava na construção, reparação ou na ornamentação de templos onde mais de uma irmandade tinha sede.

De qualquer das maneiras, a evidência dos antagonismos vigentes entre as irmandades parece ter aflorado mais enfaticamente por intermédio das festas por elas promovidas e pelas/nas procissões de que participavam. Decorrentes das determinações tridentinas, as festas do calendário litúrgico e de homenagem aos santos padroeiros das irmandades impregnaram, desde o momento inicial, o exercício da religiosidade nas terras coloniais.

Nas festas, prenhes de feições profanas, as irmandades procuravam exibir o seu poder e alcançar ou reforçar o seu prestígio social. Nesses espetáculos lúdicos eram flagrantes as desigualdades sociais. Ao mesmo tempo, por meio deles, os sodalícios aspiravam atrair e captar simpatias das autoridades civis e eclesiásticas e da sociedade em geral para aspectos que fugiam à ortodoxia e aos padrões culturais dos brancos.

Nessas circunstâncias, dos eventos mais significativos eram as coroações de reis e rainhas de irmandades de africanos e seus descendentes acontecimentos que reviviam a cristianização do reino do Congo no final do século XV. Eles existiam nas mais diferentes partes do Brasil colonial, ainda que guardando especificidades dos momentos e das regiões em que se desenvolviam. Possivelmente presente em Portugal desde o século XVI, estendiam-se à vizinha Espanha e às suas possessões americanas, o mesmo ocorrendo nas colônias inglesas da América do Norte (Mello e Souza, 2002, p.207-11).9

Reisados e congadas deram novo sentido semântico aos rituais católicos na América portuguesa. Um retorno às culturas religiosas primitivas, onde não estiveram ausentes práticas do candomblé ou do acotundá, ainda que elas como o calundu (esta, sem traços de sincretismo religioso) se exprimissem apartadas 
das irmandades. Não sendo exclusivo dessas manifestações, foram as irmandades de negros e de seus descendentes, no entanto, que, pelo seu traço institucional, viriam a favorecer a sobrevivência das mesmas.

Acrescente-se que a eleição de reis e rainhas, os cortejos deles decorrentes e o exercício das funções pelos escolhidos tinham impacto político, pois expressavam coesão social e revelavam lideranças no interior das irmandades, para além de se constituírem em polos aglutinadores das comunidades a que pertenciam. Por decorrência, variando no tempo, no lugar e em circunstâncias, despertavam sentimentos e atitudes ambíguas nas autoridades civis e eclesiásticas. De aceitação, mas também de repulsa. "No mais das vezes, porém, o sentimento era de preocupação e desagrado", sobretudo, porque, ademais dos desregramentos religiosos, "eram percebidos também como atos políticos desestabilizadores, que precisavam ser reprimidos" (Lara, 2007, p.210-18).

\section{Outros tempos}

No settecento já não havia tanta ênfase na redução de pagãos ao cristianismo. Já não havia o sentido de busca (por vezes desenfreada) de novos adeptos ao cristianismo. $\mathrm{Na}$ altura, tratava-se mais de consolidar o catolicismo como crença oficial do Estado, mais do que nunca subordinando ações religiosas aos interesses e às vontades da política colonizadora. Nessa dimensão é que, para exemplificar e como referido, o batismo aos negros escravizados ainda na África ou nos portos do seu desembarque na América portuguesa constituía-se menos num ato de conversão religiosa do que num fator legitimador e sacralizador da escravização naquele contexto praticada.

Agora, grosso modo, as irmandades coloniais, sem abandonar a sua essência religiosa-espiritual e assistencialista, estiveram mais voltadas para a satisfação de carências econômicas, sociais e políticas dos seus membros. O seu desatrelamento das ordens religiosas foi sendo constante, trazendo-lhes maior grau de autonomia e de liberdade nas suas escolhas e decisões. Mais do que nos séculos anteriores, funcionaram como espaço e instrumento de uma solidariedade grupal mais efetiva, de integração e identidade social, mas também, e inerentemente, foram palco de conflituosidades intra e extrainstitucionais.

Com efeito, naquela centúria, a Igreja-instituição foi-se posicionando à margem do processo de disseminação do catolicismo nas colônias portuguesas. Já não se via trabalho de evangelização stricto sensu. A fragilidade e o desinteresse das ordens religiosas e a supressão da Companhia de Jesus são ilustrativos de como se abriram alternativas para a emergência e a disseminação de formas de expressão católicas que já não mais se subordinavam às orientações impressas pelas congregações religiosas na expansão e na consolidação da fé católica no império.

A ação missionária como missão de libertação não tinha mais o elã e a vitalidade de outrora. O que se via, então, era conformismo, omissão, ou seja, corroboração aos avanços avassaladores do Estado absoluto português e a trans- 
ferência da responsabilidade dos encargos financeiros e da realização dos ofícios religiosos para os leigos.

Aliás, em matéria de libertação, registre-se a expectativa de obtenção de alforrias de escravos por intermédio das confrarias a que esses se filiavam. Acentuando os laços de solidariedade e de proteção aos seus adeptos, várias foram as irmandades do Rosário que clausulavam nos seus compromissos o dever de libertar da escravidão os seus irmãos cativos, constituindo fundos pecuniários próprios para essa finalidade. Para tanto, algumas delas estipulavam taxas de admissão mais elevadas por candidatos brancos visando provisionar-se. É evidente, repita-se, que essa atitude tinha alcance limitado não comprometendo a ordem escravocrata reinante. Na realidade, não contribuía para a restituição à liberdade de um contingente significativo de escravos. Em contrapartida, mencione-se a existência de irmandades de negros possuidoras de escravos, seja por doações, seja por compra (Scarano,1975, p.73; Soares, 2000, p.178; Lima,1999, p.20-1).

\section{Ocaso}

No século XVIII, período regalista por excelência, surpresa seria se o Estado português não tivesse controle sobre as associações leigas. Antes disso, o seu poder de ingerência já evidenciara, como no ato de confirmação dos compromissos e nas tomadas de contas efetuadas pelos provedores de comarcas, procedimentos esses previstos e prescritos nas Ordenações do Reino. O que alterou foram a ênfase e o modus operandi que se tornaram mais rigorosos no século XVII, inclusive porque o Estado passou a imiscuir-se em questões de natureza religiosa que até então estavam afetas ao arbítrio e às decisões episcopais.

Seja como for, a autonomia e a independência iniciais das confrarias foram sendo limitadas e restringidas. O Estado buscava ser protagonista exclusivo nas ações que dissessem respeito à fiscalização daquelas associações. A partir da administração do marquês de Pombal (1755-1777), há firme e continuada determinação do Estado em retirar às autoridades eclesiásticas a tutela e a fiscalização das irmandades. A competência de os bispos tomarem as contas dessas associações, naqueles casos previstos nas Ordenações do Reino, foi sendo cada vez mais questionada na segunda metade do século XVIII. Em resumo, com o aproximar do final da centúria, pelo enunciado de sucessivas provisões régias ou emanadas da Mesa da Consciência e Ordens, tornava-se flagrante a tendência à laicização e secularização das confrarias.

Nessa etapa de complexificação da sociedade colonial, quanto mais repressiva e opressora se mostrava a ação do Estado português setecentista, mais fortalecidos se faziam os movimentos associativos da população. A comprovar essa afirmativa o exame das datas de criação ou de revigoramento das irmandades naquelas partes do império nas quais a conduta acima referida se mostrou mais incidente.

Destarte, verificou-se uma significativa expansão numérica das confrarias. Quanto àquelas compostas por camadas superiores da sociedade, a expansão 
evidenciou-se, por exemplo, pelo advento de um maior número de ordens terceiras ou de suas presídias, ambas formas de sociabilidades que retratavam uma economia que se diversificava produtivamente e uma estratificação social que se ia consolidando. No outro extremo social, o movimento expressou-se tanto pela multiplicação das irmandades de Nossa Senhora do Rosário, ${ }^{10}$ como pelas de invocações correlatas (v.g., São Benedito e São Elesbão) e pela ocorrência de confrarias de Nossa Senhora das Mercês, consagrada privilegiada e principalmente à redenção dos cativos.

Assinale-se que, em simultâneo, a criação espontânea de novas irmandades ficava inibida pela divulgação de determinações régias pertinentes, como se lê em provisões de 17 de novembro de 1766 e de 12 de setembro de 1767, que reafirmavam a hierarquia do Estado também nessa matéria, posto que insistia em declarar que a faculdade de se erigir irmandades e confrarias e a de aprovar os seus compromissos era privativa do grão-mestre das ordens e de sua jurisdição régia.

A constatar, além disso, que, na altura (segunda metade do século), a criação de novos núcleos urbanos resultava automaticamente no advento de novas confrarias, como expressão quer de solidariedade grupal religiosa, quer dos interesses temporais e sociais das populações dos aglomerados emergentes.

Assim, a proliferação das confrarias no ultramar levou a coroa a precaver-se quanto ao controle que sobre elas exercia. Em 7 de março de 1794, o ministro de Estado Martinho de Melo e Castro, dirigindo-se aos deputados da Mesa da Consciência e Ordens, a eles encarecia cuidado especial para com os assuntos confrarias. Dizia:

É muito para recear que todo o Brasil se acha inundado de semelhantes associações debaixo do título de confrarias e irmandades, sem que se saiba o número delas, nem os indivíduos de que cada uma se compõem, nem se todas ou maior parte seguem o mesmo criminoso sistema das Minas Gerais [...]. Sendo bem conhecidos os danos que têm resultado aos estados soberanos de muitas das ditas associações eretas ao princípio debaixo do título de piedade e devoção, e convertido depois em conventículos sediciosos e origem de muitos e muitos funestos acontecimentos. (Academia das Ciências de Lisboa. Coleção de legislação portuguesa, compilada por Francisco H. de Aragão Morato, v.26, doc.186)

No seu conjunto, tempos depois, na virada do século, as confrarias não conseguiam esconder o seu declínio. Suspensões de festas, rompimento de contratos de capelães privativos, anexação e fusão de irmandades existentes na mesma igreja ou na mesma localidade, dispensa ou suspensão de contratação de músicos e de sermonistas para determinados gêneros de celebrações religiosas, restrições nas contratações ou na compra de obras de arte... Várias foram as medidas alternativas deliberadas pelas irmandades para tentar conter a evasão de quadros e a inadimplência financeira que se foram tornando comportamentos rotineiros entre elas. 


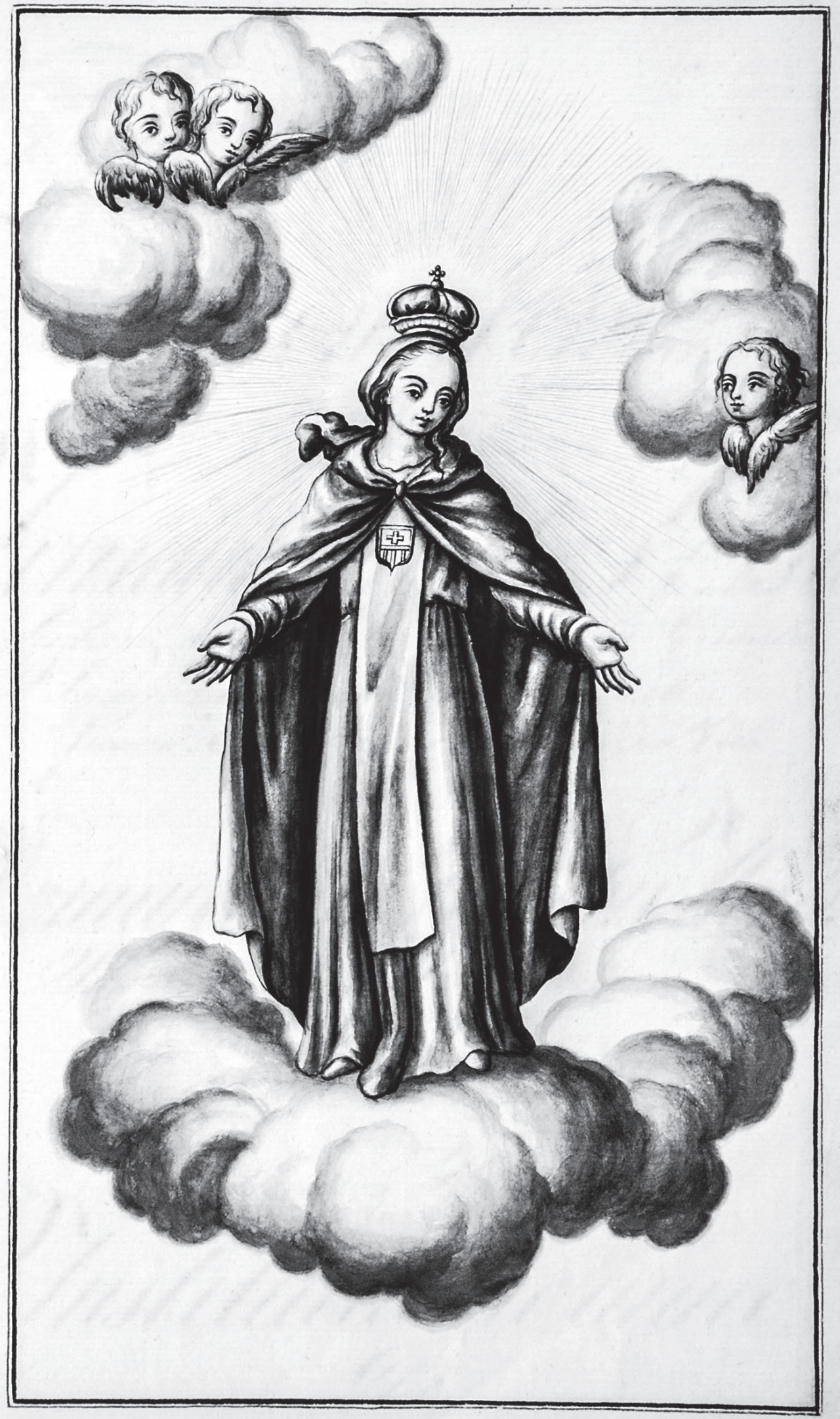




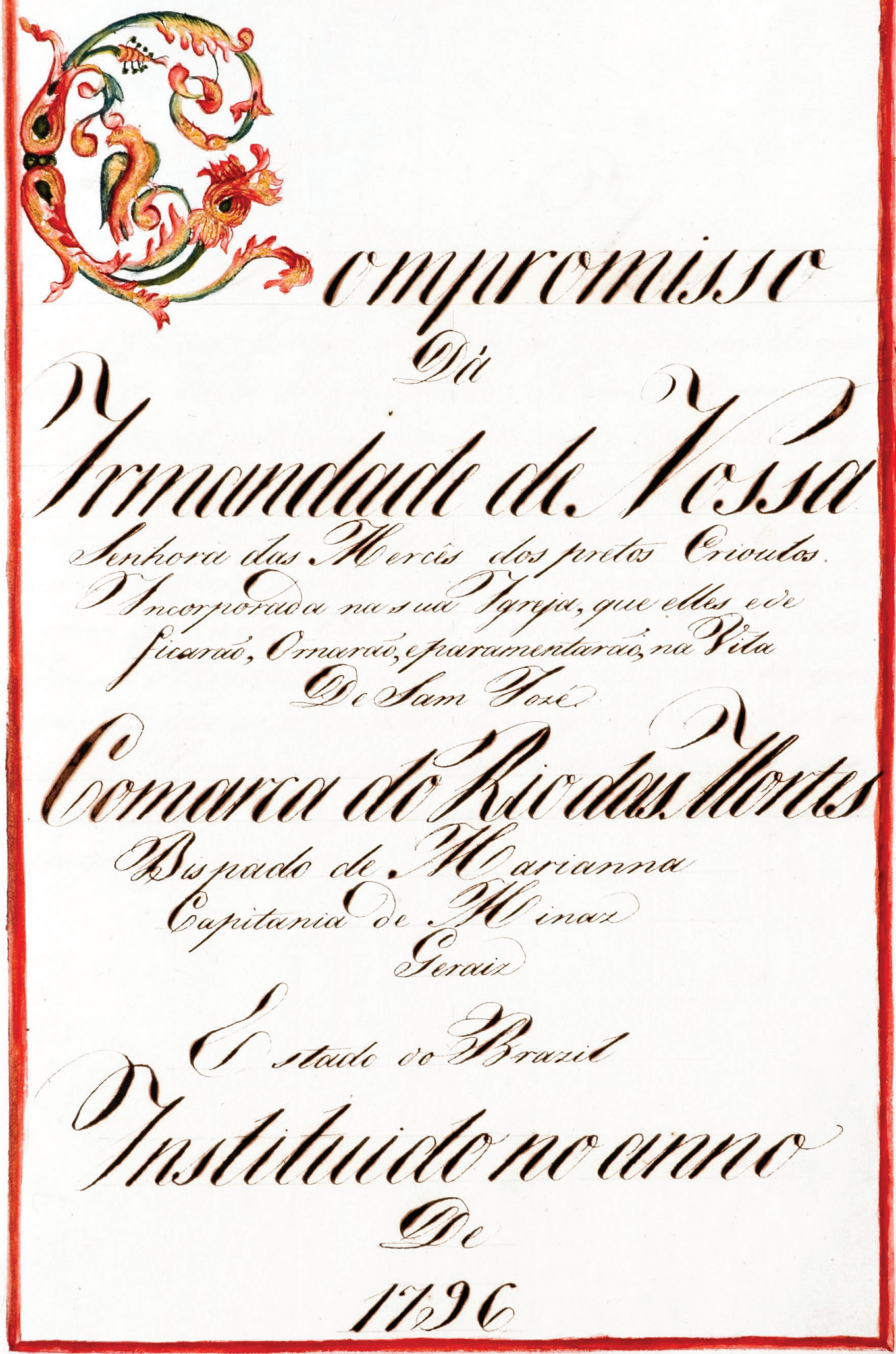


Em geral, estava-se perante um processo de dessacralização que envolvia minimamente as confrarias acentuando a sua laicização. Considere-se também que os indivíduos já não as concebiam como organizações que respondessem adequadamente aos anseios sociais naquela viragem de centúria. Cooptadas pelo Estado ou por ele cerceadas nas suas ações, as irmandades foram-se tornando cada vez mais entidades de perfil conservador e já não mostravam ser ambiente de liberdade e de autonomia para as sociedades ultramarinas.

\section{À guisa de conclusão}

No Brasil colonial, para os negros, as irmandades se apresentavam como forma de sociabilidade, organismo de relativa autonomização e forma de ação coletiva e de (re)construção de identidade. Nelas, praticaram o catolicismo, mas conservaram suas matrizes culturais. Aninharam-se na religião dos brancos, mas fizeram das irmandades instrumento de resistência cultural. Assim, ao mesmo tempo em que expressavam uma forma de sincretismo religioso no processo de cristianização do negro, essas agremiações representavam também uma das poucas - se não a única - das formas de associação permitidas à população de cor no interior do mundo colonial. A ação protetora da irmandade passava, naquela conjuntura, a ser a determinante básica da adesão do negro àquelas associações. Isso explica também, a par do distanciamento temporal e da inexistência de fontes, a identidade e a sinceridade dos laços de coesão grupal entre a população escrava. Não seria mesmo arriscado afirmar que tais laços foram mais duradouros e permanentes nesse segmento social.

Se é verdade que as irmandades de negros não lutaram pelo fim do sistema escravista, não é menos verdade que, sem elas, certamente desapareceria qualquer propósito de solidariedade intragrupal. Embora não objetivassem a destruição do sistema, as irmandades davam aos negros a oportunidade de desabafar suas agruras, expressar suas necessidades e, até mesmo, tentar influir em seu futuro, procurando tornar suas vidas mais suportáveis. Por isso, elas foram palco distinguidor da sociabilidade praticada na colônia. E, nessa medida, os negros souberam utilizar-se delas como veículo de defesa e de proteção contra os rigores da escravidão.

O sentimento e a prática da solidariedade inerentes às irmandades, que se expressavam desde as voluntárias vontade e iniciativa de se aderir a uma ou mais associação, infundiam nos negros a insubstituível sensação de que, naquelas circunstâncias e naquele espaço, eles podiam se sentir um pouco bumanos. A irmandade, mais do que território do sagrado e do transcendente, era locus legal e legitimado onde os negros se podiam perceber minimamente livres e desenvoltos para deliberar e para agir. Nessa medida, no âmbito das irmandades, e por intermédio delas, os negros se impuseram como ativos sujeitos de suas vontades e interesses. 


\section{Notas}

1 Este texto é caudatário de trabalhos publicados pelo autor, como sejam: Boschi (1986; 1998a; 1998b; 2007). Pretende-se incorporar a eles parte de importantes contribuições historiográficas publicadas nos últimos anos.

2 Sobre o catolicismo na África, consulte-se também Palmer (1998); Heywood (2002); Thornton (1988); Gomez (1998); Lovejoy (2002); Bastide (1971); Mintz; Price (1992).

3 Sobre as irmandades de negros africanos e de seus descendentes na América portuguesa, recorra-se também a Russell-Wood (1974); Figueiredo (1994); Torres (1997); Pinheiro (2006); Higgins (1999); Karasch (1987); Simão (2010); Mulvey (1976); Assis (1988).

4 Ressalve-se que "a despeito da inegável eficácia do projeto formulado pela Ordem do Carmo com vistas à catequese do elemento negro, $[\ldots]$ o estudo do culto de Santo Elesbão e de Santa Efigênia permite a avaliação e compreensão das contradições e limites dos projetos de poder [...] a difusão do culto [desses santos] demonstrou que este discurso impositivo teve que buscar matizes e adaptações à realidade" (Oliveira, 2008, p.323-4).

5 A quase obsessão com a salvação das almas impulsionava as populações coloniais a erigir confrarias sob tal invocação. Basta dizer que, dentre 322 associações leigas identificadas nas Minas Gerais do século XVIII, 35 delas, isto é, 10,9\%, tinham as almas como orago, sendo quantitativamente superadas apenas pelas irmandades de Nossa Senhora do Rosário e do Santíssimo Sacramento. Cf. Boschi (1986, p.187-8).

6 “[...] o pagamento do enterro, a celebração das missas e as esmolas deixadas para as irmandades são compromissos anteriores à constituição de um patrimônio familiar a ser deixado para a descendência" (Soares, 2002, p.67). Sobre a salvação das almas e respectivas irmandades, ver Campos (1994; 2013); Ramos (2001).

7 "Entre os vários erros de interpretação que contaminavam a relação entre europeus e centro-africanos, talvez a mais significativa era a que envolvia o sacramento do batismo. Existem muitas provas de que, para os centro-africanos, o batismo equivalia ao ato de comer sal” (Sweet, 2007, p.229). "[...] Segundo as crenças tradicionais congolesas, o sal era visto como um repelente de pessoas e espíritos maldosos. Assim, acreditava-se que o mal poderia ser evitado através do batismo cristão, ou seja, através do consumo de sal" (ibidem, p.230).

8 Sobre a exclusividade de ocupação de cargos administrativos das irmandades por grupos ou segmentos sociais, ver, dentre outros: Russell-Wood (1981, p.108); Soares (2000, p.188); Reginaldo (2011, p.158-9); Silva (2003, p.82 e 91).

9 Recorra-se também a Scarano (1975); Soares (2000); Borges (2005); Lahon (2001); Quintão (2002); Kiddy (2005; 2000); Parès (2006). A salientar as diferenciações e singularidades dos reinados festivos e das congadas, de acordo com os vários contextos da América portuguesa, como anunciam os vocábulos designativos: reisados, congados, candomblé, candombe, catopê, maracatu etc.

10 Por exemplo, 16 irmandades foram constituídas pela população de cor nas oito freguesias da cidade de Salvador da Bahia no século XVIII, e sete delas, as mais numerosas, tinham como devoção a Senhora do Rosário dos Pretos, seguida de São Benedito (três irmandades) (Reginaldo, 2011, p.123). Para um total de 322 associações leigas identificadas nas Minas Gerais setecentistas, 62 delas, isto é, 19,31\%, evocavam esse orago, sendo as mais numerosas na capitania (Boschi, 1986, p.187-8). 


\section{Referências}

ASSIS, V. A. Pretos e brancos, a serviço de uma ideologia de dominação (casos das irmandades do Recife). Recife, 1988. Dissertação (Mestrado) - Universidade Federal de Pernambuco. Recife, 1988.

BASTIDE. R. As religiões africanas no Brasil; contribuição a uma sociologia das interpretações das civilizações. São Paulo: Pioneira; Edusp, 1971.

BORGES, C. M. Escravos e libertos nas irmandades do Rosário; devoção e solidariedade em Minas Gerais - séculos XVIII e XIX. Juiz de Fora: Editora UFJF, 2005.

BOSCHI, C. C. Os leigos e o poder; irmandades leigas e política colonizadora em Minas Gerais. São Paulo: Ática, 1986.

. O enquadramento religioso. In: BETHENCOURT, F.; CHAUDHURI, K. (Dir.) História da expansão portuguesa. Lisboa: Círculo de Leitores, 1998a. v.2, p.387455 .

. A presença religiosa. In: BETHENCOURT, F.; CHAUDHURI, K. (Dir.) História da expansão portuguesa. Lisboa: Círculo de Leitores, 1998b. v.3, p.293-5.

. Como os filhos de Israel no deserto? (ou: a expulsão de eclesiásticos em Minas Gerais na $1^{a}$ metade do século XVIII). Varia História, Belo Horizonte, n.21, p.11941, 1999. (Número especial. Códice Costa Matoso).

. Em Minas, os negros e seus compromissos. In: MARTINS FILHO, A. V.

(Ed.) Compromissos de irmandades mineiras do século XVIII. Belo Horizonte: Claro Enigma; Instituto Cultural Amilcar Martins, 2007. p.275-93.

CAMPOS, A. A. A terceira devoção do Setecentos Mineiro: o culto a São Miguel e Almas. São Paulo, 1994. Tese (Doutorado) - Faculdade de Filosofia, Letras e Ciências Humanas, Universidade de São Paulo. São Paulo, 1994.

As irmandades de São Miguel e as almas do Purgatório: culto e iconografia no Setecentos mineiro. Belo Horizonte: C/Arte, 2013.

FIGUEIREDO, A. M. Os reis de mina: a Irmandade de Nossa Senhora dos homens pretos no Pará do século XVII ao XIX. Boletim do Musen Paraense Emilio Goeldi - Antropologia, Belém, v.9, n.1, p.103-21, 1994.

GABRIEL, M. N. Angola, cinco séculos de Cristianismo. Queluz: Literal, 1978.

GOMEZ, M. A. Exchanging our country marks: the transformation of African identities in the colonial and antebellum south. Chapel Hill: University of North Carolina Press, 1998.

HEYWOOD, L. (Ed.) Central Africans and cultural transformations in American Diaspora. Cambridge: Cambridge University Press, 2002.

HIGGINS, K. J. “Licentious Liberty” in a Brazilian Gold-Mining Region (...). Pennsylvania: Penn State University Press, 1999.

KARASCH, M. Slave life in Rio de Janeiro, 1808-1850. Princeton: Princeton University Press, 1987.

KIDDY, E. W. Blacks of the Rosario: memory and history in Minas Gerais, Brazil. Pennsylvania: Penn State University Press, 2005. 
KIDDY, E. W. Congados, calunga, candombe: Our Lady of the Rosary in Minas Gerais, Brazil. Luso-Brasilian Review, v.37, n.1, p.47-61, 2000.

LAHON. D. O negro no coração do Império; uma memória a resgatar, séculos XV-XIX. Lisboa: Secretariado Coordenador dos Programas Multiculturais - Ministério da Educação, 1999.

Esclavage et confréries noires au Portugal durant l'Ancien Régime (14411830). Paris, 2001. Thèse (Docteur en Anthropologie Sociale) - École des Hautes Études en Sciences Sociales. Paris, 2001. 2v.

LARA, S. H. Fragmentos setecentistas; escravidão, cultura e poder na América portuguesa. São Paulo: Cia. das Letras, 2007.

LIMA, C. A. M. Em certa corporação: politizando convivências em irmandades negras no Brasil escravista (1700-1850). História: Questões \& Debates, Curitiba, n.30, p.11-38, 1999.

LOVEJOY, P. E. A escravidão na África: uma história de suas transformações. Rio de Janeiro: Civilização Brasileira, 2002.

MELLO E SOUZA, M. de. Reis negros no Brasil escravista; história da festa de coroação de rei Congo. Belo Horizonte: Editora UFMG, 2002.

MINTZ, S. W.; PRICE, R. The birth of African-American Culture: an anthropological perspective. Boston: Beacon, 1992.

MULVEY, P. A. The black laybrotherhoods of Colonial Brazil; a history. New York. Dissertation (Ph.D) -University of New York. New Yoik, 1976.

OliveIRA, A. J. M. de. Devoção negra; santos pretos e catequese no Brasil Colonial. Rio de Janeiro: Quartet; Faperj, 2008.

PALMER, C. A. Passegeways: an interpretative history of Black America. Fort Worth: Harcourt Brace, 1998. 2v.

PARÈS, L. N. A formação do candomblé: história e ritual da nação jeje na Bahia. Campinas: Editora da Unicamp, 2006.

PINHEIRO, F. A. D. Confrades do Rosário: sociabilidade e identidade étnica em Mariana, Minas Gerais (1745-1820). Niteroi, 2006. Dissertação (Mestrado) - Universidade Federal Fluminense. Niteroi, 2006.

QUINTÃO, A. A. Lá vem parente; as irmandades de pretos e pardos no Rio de Janeiro e em Pernambuco (século XVIII). São Paulo: Annablume; Fapesp, 2002.

RAMOS, D. A luta pela alma: conflito espiritual nas Minas Gerais do século XVIII. Oficina da Inconfidência: Revista de Trabalho, Ouro Preto, v.2, n.1, p.13-46, 2001.

REGINALDO, L. Os Rosários dos Angolas; irmandades de africanos e crioulos na Bahia Setecentista. São Paulo: Alameda, 2011.

RUSSELL-WOOD, A. J. R. Black and mulato brotherhoods in Colonial Brazil: a study in collective behavior. Hispanic American Historical Review, v.54, n.4, p.567-602, 1974.

Fidalgos e filantropos: a Santa Casa de Misericórdia da Bahia, 1550-1755. Brasília: Editora da Universidade de Brasília, 1981. 
SCARANO, J. Devoção e escravidão; a Irmandade de Nossa Senhora do Rosário dos pretos no Distrito Diamantino no século XVIII. São Paulo: Nacional; Conselho Estadual de Cultura, 1975. (Col. Brasiliana, v.357).

SILVA, L. G. Religião e identidade étnica; africanos, crioulos e irmandades na América portuguesa, Cahiers des Amériques Latines, Paris, v.44, n.3, p.77-96, 2003.

SIMÃO, M. S. As irmandades de Nossa Senhora do Rosário e os africanos no Brasil do século XVIII. Lisboa, 2010. Dissertação (Mestrado em História) -Universidade de Lisboa. Lisboa, 2010.

SOARES, M. de C. Devotos da cor; identidade étnica, religiosidade e escravidão no Rio de Janeiro, século XVIII. Rio de Janeiro: Civilização Brasileira, 2000.

O império de Santo Elesbão na cidade do Rio de Janeiro, no século XVIII, Topoi, Rio de Janeiro, v.3, n.4, p.59-83, 2002.

SWEET, J. H. Recriar África, cultura, parentesco e religião no mundo afro-português (1441-1770). Lisboa: Edições 70, 2007.

THORNTON, J. Africa and Africans in the making of the Atlantic World, 1400-1800. Cambridge, Cambridge University Press, 1988.

TORRES, C. V. Um reinado de negros em mundo de brancos; organização de escravos urbanos em Recife no final do século XVIII e início do XIX (1774-1815). Recife, 1997. Dissertação (Mestrado) - Universidade Federal de Pernambuco. Recife, 1997.

RESUMO - A propagação da fé católica na América portuguesa, embora responsabilidade formal dos reis lusitanos e atributo dos quadros eclesiásticos, teve nas irmandades, confrarias e ordens terceiras os seus efetivos esteios e promotores. Espaços de vivência religiosa e de sociabilidade, essas agremiações leigas se disseminaram pelo território colonial. Ainda que inspiradas em suas congêneres da metrópole, guardavam consideráveis traços de originalidade, sobretudo aquelas organizadas e mantidas pela majoritária população negra, de origem africana. As irmandades de "homens de cor", as mais numerosas, ao reinterpretarem o catolicismo, foram, assim, expressões de incorporação desses segmentos sociais ao mundo dos brancos e, em simultâneo, veículos de resistência cultural.

PALAVRAS-CHAVE: Catolicismo negro, Irmandades, Antigo Regime, Regalismo, Resistência cultural.

ABSTRACT - The propagation of the catholic faith in Portuguese America, although formally the responsibility of Lusitanian kings and an attribute of ecclesiastical personnel, found in its brotherhoods, confraternities and third orders effective supporters and promoters. As spaces of religious experiences and sociability, those lay associations spread throughout the colonial territory. Although inspired by their counterparts in the Metropolis, they kept marked traces of originality, especially those organized and maintained by the majority black population of African origin. The brotherhoods of "colored men", which were the most numerous, by reinterpreting Catholicism were an expression of the incorporation of those social segments into the white world and, at the same time, vehicles of cultural resistance. 
KErWORDS: Black catholicism, Brotherhoods, Ancien Régime, Regalism, Cultural resistance.

Caio C. Boschi é doutor em História Social pela Universidade de São Paulo. Professor titular do Departamento de História da Pontifícia Universidade Católica de Minas Gerais. @ - caioboschi@hotmail.com / https://orcid.org/0000-0003-0665-2563

I Pontifícia Universidade Católica de Minas Gerais, Belo Horizonte, Minas Gerais. Brasil.

Recebido em 31.5.2019 e aceito em 22.6.2019. 
